\title{
EFFECT OF THE DISINFECTION TECHNIQUE ON THE LINEAR DIMENSIONAL STABILITY OF DENTAL IMPRESSION MATERIALS
}

\author{
EFEITO DA TÉCNICA DE DESINFECÇ̃O SOBRE A ESTABILIDADE DIMENSIONAL \\ LINEAR DOS MATERIAIS DE MOLDAGEM ODONTOLÓGICOS
}

Sávio Marcelo Leite Moreira da SILVA ${ }^{1}$, Milton Carlos Gonçalves SALVADOR ${ }^{2}$

\author{
1- Full Professor, Technical School of Federal University of Paraná. Associated Professor, School of Dentistry, Unicenp, Curitiba, \\ Paraná , Brazil. \\ 2- Doctor Professor, Prosthodontic Department, Bauru dental School, University of São Paulo. \\ Corresponding address: Sávio Moreira da Silva - Av. Pe. Agostinho, 2885, ap.1704 - B3, Bigorrilho, Curitiba-PR - CEP 80.710-000
} FONE: (41) 3234897 / 3366876 / 99732861 - E-mail: savio@ufpr.br

Received: June 06, 2003 - Returned for modification: August 08, 2003 - Accepted: April 19, 2004

\begin{abstract}
T immersion in disinfectant solution for 10 or 20 minutes. The impression materials were Optosil Comfort and Xantopren VL Plus and the disinfectant solutions were $1 \%$ sodium hypochlorite and $2 \%$ glutaraldehyde. Impressions were made on a perforated stainless steel tray, according to the American Dental Association specification No. 19, adding up to a total of 50 samples. The double mixing method (one time, two viscosities) was used. Impressions were removed from the roulette block after 7 minutes to ensure complete curing and then immersed in the solutions. Impressions not submitted to treatment composed the control group. After these steps, the impressions were removed from the solution, rinsed in running water and air-dried. Threedimensional measurements were calculated using an optic microscope graduated at $0.001 \mathrm{~mm}$. The two-way ANOVA indicated no differences $(p>0.05)$ for any combination between variables. The results showed that the solution studied can be safely used to disinfect condensation silicone in clinical prosthodontic procedures.

Uniterms: Dental impression materials; Silicone elastomers; Disinfection; Dimensional stability.
\end{abstract}

\begin{abstract}
RESUMO
$\mathrm{O}$

objetivo deste trabalho foi avaliar a estabilidade dimensional das siliconas de condensação pesada e leve para moldagem odontológica, quando imersas em solução desinfetante por 10 e 20 minutos, relacionando a importância da biossegurança no manuseio destes materiais. Os materiais de moldagem testados foram: Optosil Confort e Xantopren VL Plus; e as soluções desinfetantes foram o hipoclorito de sódio a 1\% (Solução de Milton) e o glutaraldeído a 2\% (Glutaron II). Impressões foram obtidas através de moldeiras perfuradas de aço inoxidável, de acordo com a especificação n. ${ }^{\circ} 19$ da ADA, perfazendo um total de 50 moldagens, que foram executadas pela técnica em passo único. Para assegurar a completa polimerização o material foi removido após 7 minutos e submetido à imersão nas soluções desinfetantes nos tempos determinados, sendo um grupo controle representado por moldes sem imersão. Depois de removidos das soluções, os corpos de prova foram lavados em água corrente por 15 segundos, secos e medidos 3 vezes cada para registro da média, usando um microscópio óptico, com precisão de 0,001 mm. A análise de variância a dois critérios, com nível de significância de 5\%, mostrou que as diferenças nas dimensões lineares da silicona testada não são estatisticamente significantes ( $>>0,05)$ após sua imersão em solução de hipoclorito de sódio a $1 \%$ e glutaraldeído a $2 \%$ até 20 minutos. Os resultados indicaram que as soluções testadas podem ser seguramente empregadas na desinfecção de siliconas de adição durante os procedimentos clínicos de reabilitação protética.

Unitermos: Elastômeros de silicone; Materiais para moldagem odontológica; Desinfecção; Alterações dimensionais.
\end{abstract}




\section{INTRODUCTION}

Contamination of the working atmosphere by several microorganisms from the oral flora during the clinical practice of dentistry offers constant risks to the health professionals. Strong evidences have been shown in the literature regarding the pathogenesis and intensity of the viruses of hepatitis B (HBV), herpes, tuberculosis and acquired immunodeficiency syndrome (AIDS) in dentistry ${ }^{23}$.

Dental impressions consist of taking into the mouth a material able to register the anatomical relief of the area desired that is dimensionally stable. The impression then displays the anatomy of the impressed area. During this procedure, the material has contact with saliva and blood, which are sources of contamination, and carries a great number of microorganisms of the oral flora upon removal from the mouth. Some of the several types of impression materials currently employed in dentistry have a great potential to retain microorganisms on their surfaces. Poulos and Antonoff ${ }^{20}$ (1997) stated that the polyvinyl siloxane is the most resistant to the retention of microorganisms, followed by the polysulphate. Besides, the number of microorganisms in these materials is quickly reduced through disinfection procedures. Reversible and irreversible hydrocolloids, both hydrophilic, are the materials that retain more bacteria after impression ${ }^{20}$.

The top concern of dental professionals is mainly related to the dimensional alteration of the impressions in procedures involving high dimensional precision. Rivers, et al. ${ }^{21}$ (1996) stated that many dentists avoid to accomplish disinfection by immersion, giving preference to the aerosols, fearing distortions of the impression. However, the aerosol treatment of an impression with a disinfectant cannot be so effective in the destruction of microorganisms as the immersion for 30 or 60 minutes in a high level disinfectant ${ }^{21}$. The efficiency of disinfection methods and their consequences on the impression materials are being investigated since $1974^{30}$. Leung and Schonfeld ${ }^{10}$ (1983) observed the transfer of microorganisms from the impressions to the plaster casts, bringing about a risk of contamination to the laboratories of dental prosthesis. Therefore, the disinfection of impressions is a fundamental procedure in the routine dental practice ${ }^{11}$. Some methods have been proposed to eliminate the microorganisms from the surface of the materials after impression. The Brazilian Ministry of Health recommends the employment of liquids for disinfection by physical or chemical action ${ }^{2}$. Since the physical action yields an increase in temperature, just the solutions of chemical action may be applied in dental impressions. Such disinfectant agents have their action decreased or even inactivated in the presence of organic remnants. This explains the need of previous washing of the impressions before disinfection. The wash itself removes most of the contamination, but is not enough to eliminate all the contamination ${ }^{14}$. Glutaraldehyde and formaldehyde solutions act in the fixation of the cell membrane, blocking the release of cellular components and consequently killing the microorganisms. Chlorhexidine, phenols, alcohols and ammonium quaternary compounds, which work as a protoplasmatic poison, act on the cell membrane and cause loss of nucleic acids and potassium, vital cell components. Halogenous disinfectants such as chlorinated and iodized compounds constitute a third type of chemical formulation, the performance of which is based on the cell oxidation ${ }^{24}$. Alcohols are counter-indicated for disinfection of impression materials, because their action depends on friction of the surface. The formaldehyde should be avoided because of its concomitant carcinogenic action. Iodine solutions should also not be used for disinfection ${ }^{2}$. The ammonium quaternary compounds have a low level of action and also require friction ${ }^{2}$, even though they have a small effect on the dimensional stability of the condensation silicone Optosil - Xantopren and some other materials ${ }^{28}$. On the other hand, synthetic phenols act better under friction, display acute toxicity and are incompatible with latex, acrylic and rubber $^{2}$. The sodium hypochlorite solution, employed in this study, has a medium level action. So, the surface should be exposed to a concentration of $1 \%$ of active chlorine $(10,000$ ppm) for 10 minutes. Its disadvantage lies on its corrosive potential to the metal trays. Osório, et al. ${ }^{17}$ (1997) showed the effectiveness of immersion in $2 \%$ sodium hypochlorite for 10 minutes in the disinfection of alginate impressions. However, Merchant, et al. ${ }^{14}$ (1984) stated that a concentration of just $0.5 \%$ is enough to disinfect several impression materials. Glutaraldehyde is a high-level disinfectant and is not as corrosive as hypochlorite. Alkaline and neutral glutaraldehydes are less corrosive than the acidic glutaraldehyde. They are suitable for utilization in a concentration of $2 \%$ for 30 minutes $^{2}$. Osorio, et al. ${ }^{17}$ (1997) achieved efficient disinfection with immersion for just 10 minutes.

Considering the studies accomplished on this subject and the contradictions among them, the aim of this study was to elucidate possible dimensional alterations that may occur in condensation silicone impressions after disinfection by immersion in $1 \%$ sodium hypochlorite and $2 \%$ glutaraldehyde, ranging the immersion time from 10 to 20 minutes.

\section{MATERIALAND METHODS}

Fifty specimens were obtained with the condensation silicone Optosil comfort and Xantopren VL Plus, manufactured by Heraeus Kulzer - Germany, by means of a stainless steel device, according to specification No. 19 of the American Dental Association - $\mathrm{ADA}^{1}$, comprising a roulette block and an impression tray divided in two parts: a ring and a perforated base (Figures 1 and 2).

The light and heavy impression materials were dispensed and manipulated for impression in a single step, following the manufacturer's instructions. The heavy material was manipulated for 30 seconds for homogenization of the universal activator and then inserted in the tray. Simultaneously, $4 \mathrm{~cm}$ of the light material and universal activator were dispensed and mixed on a glass slab for 30 
seconds with a spatula \#36. The light material was inserted on the tray over the heavy material.

The roulette block was positioned on the tray and pressed against the material until fitting in the tray. A 1-kg weight maintained the impression tray in position against the roulette block for 7 minutes for curing of the material. After this period, the metallic cylinder was separated from the tray. Then, the ring that composed the tray was separated from the perforated base that retained the impression material. Both impression and base were rinsed in running water for 15 seconds and air-dried. After these steps, the specimens were submitted to different situations:

1. Immediate measurement of the dry material and at 10 and 20 minutes after maintenance on the table without immersion. (Control group).

2. 10 -minute immersion in $1 \%$ sodium hypochlorite solution - Milton Solution - Miyako - Brazil.

3. 20 -minute immersion in $1 \%$ sodium hypochlorite solution - Milton Solution - Miyako - Brazil.

4. 10-minute immersion in 2\% glutaraldehyde solution Glutaron II - Rioquimica-Brazil.

5. 20-minute immersion in 2\% glutaraldehyde solution Glutaron II - Rioquimica - Brazil.

After the time periods described, the specimens were washed again for 15 seconds in running water and air-dried.

The distance between points $\mathrm{A}$ and $\mathrm{B}(\mathrm{AB})$ and between points $\mathrm{B}$ and $\mathrm{D}(\mathrm{BD})$ were measured three times each and the average of the measurements was taken as a reference. These distances indicate the linear dimensional changes in the central and outlying areas of the specimens, respectively.

A light microscope* with 20x magnification and digital precision of $0.001 \mathrm{~mm}$ was used for achievement of the measurements.

Due to the high precision of the microscope, the point constituted by the internal margin of the reference lines of the elastomer was taken as a reference (Figure 2).

The initial reference for all groups was provided by the immediate measurements, called T0 ( $\mathrm{T}$ zero). All measurements taken at 10 minutes, regardless of the immersion, were called T1. Similarly, those measurements achieved at 20 minutes were called T2. The control group comprised measurements taken from the specimens kept

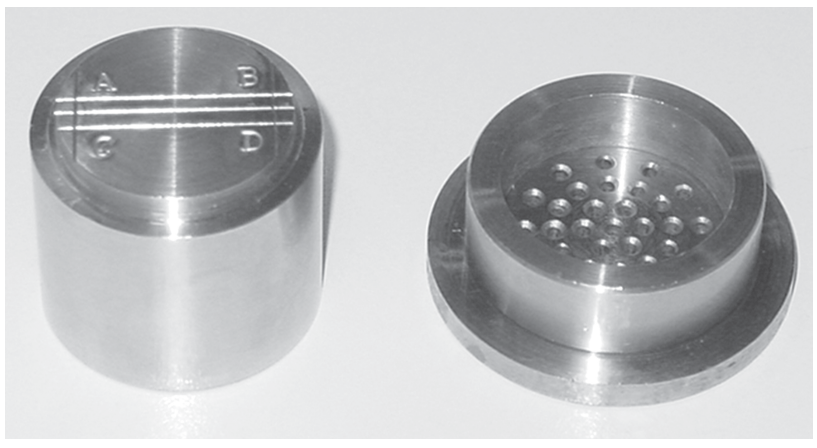

FIGURE 1- Roulette block and tray without immersion.

Data on dimensional stability were subjected to twoway analysis of variance (ANOVA). Statistical significance was defined at the $95 \%$ level of confidence.

\section{RESULTS}

Considering the control group as the baseline for evaluation of the dimensional changes, we can verify the influence of the disinfectants and time of immersion on the tested material.

Tables 1 and 2 show the group means according to the time period and the disinfectant solution.

Dimensional changes in the condensation silicone Optosil - Xantopren after 10 minutes comprised an expansion of $14 \mu \mathrm{m}$ in the $\mathrm{AB}$ distance and a contraction of $5 \mu \mathrm{m}$ in the BD distance, corresponding to $0.06 \%$ and $0.10 \%$, respectively. Considering the 20 -minute period under the same condition, the study material displayed a total expansion of $17 \mu \mathrm{m}(0.07 \%)$ in the $\mathrm{AB}$ distance and a contraction of $7 \mu \mathrm{m}(0.14 \%)$ in the BD distance.

Concerning the $1 \%$ sodium hypochlorite solution, the $\mathrm{AB}$ and $\mathrm{BD}$ distances expanded $6 \mu \mathrm{m}(0.03 \%)$ and $2 \mu \mathrm{m}$ $(0.03 \%)$, respectively, after 10 minutes of immersion. However, the group kept immersed for 20 minutes showed an expansion of $11 \mu \mathrm{m}(0.05 \%)$ in the AB distance, whereas the $\mathrm{BD}$ distance revealed an apparent initial expansion and presented a final contraction of $5 \mu \mathrm{m}$, corresponding to $0.1 \%$ of the original dimension.

The BD dimensions of specimens immersed in $2 \%$ glutaraldehyde solution presented contraction corresponding to $6 \mu \mathrm{m}(0.13 \%)$ in 10 minutes, increasing up to $7 \mu \mathrm{m}(0.14 \%)$ in 20 minutes. On the other hand, the AB distances $\mathrm{AB}$ contracted $13 \mu \mathrm{m}(0.05 \%)$ in 10 minutes in the

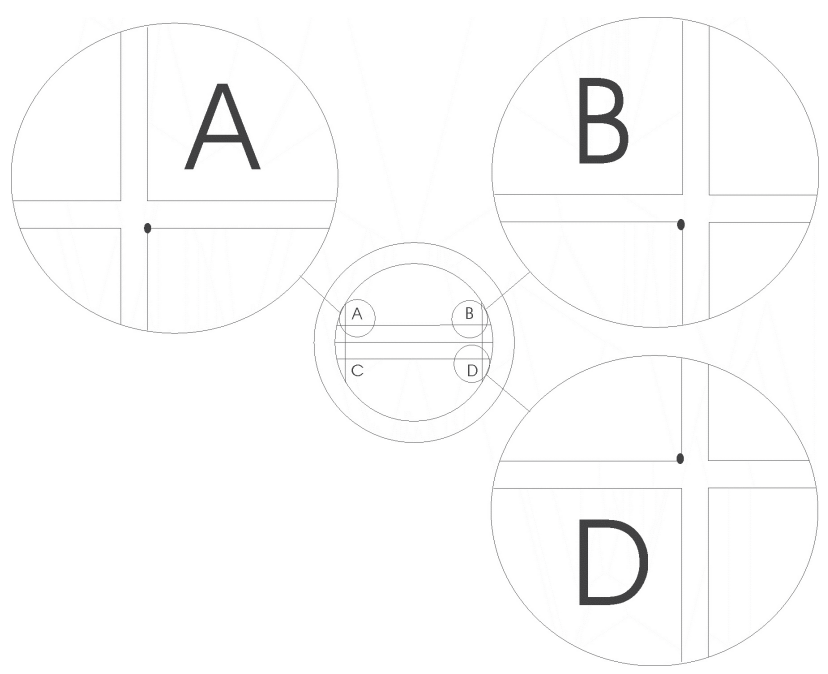

FIGURE 2- Illustration showing the reference points on samples, employed as microscopic markers 
average. After 20 minutes this contraction represented just $2 \mu \mathrm{m}$, corresponding to less than $0.001 \%$.

The variance analysis did not demonstrate significant differences between the disinfectant solutions on the dimensional stability of the silicone tested $(\mathrm{p}=0.1520)$. There was no significance as to the time period during which the material was kept immersed in the solution or left on the table ( $\mathrm{p}=0.5285$ ). Therefore, the results reject the hypothesis 1 , showing the lack of a statistically significant difference among the impressions immersed in 1\% sodium hypochlorite solution and 2\% glutaraldehyde solution, or among those kept without immersion for the time periods of 10 and 20 minutes.

\section{DISCUSSION}

Condensation silicones comprise a dimethylsiloxane polymer, the curing of which occurs in the temperature settled and yields a molecule of about one thousand units. They are commercially available as a base paste and a catalyst, in liquid or in paste form. Since the silicone polymer is liquid, colloidal silica or a metallic oxide are added in micrometric particles that act as a load. Colors are added to the materials to enhance the homogeneity obtained in the process of mixing. These should be pigments or organic dyes $^{19}$.

The formation of elastomeric compounds occurs by means of a cross link between the terminal connections of the silicone polymer and an alkylic silicate, usually the tetraethyl orthosilicate, so as to form a three-dimensional net. Ethyl alcohol is formed as a by-product of the reaction and its subsequent evaporation probably determines a larger polymerization shrinkage ${ }^{19}$.

There are many origins for the dimensional changes in dental impression materials. All elastomers exhibit a light contraction during polymerization as a result of the volume reduction due to the cross link and alcohol evaporation. This is true just for the condensation silicones. Hydrophilic silicones absorb water and expand. The incomplete elastic recovery may also give rise to impressions with different dimensions when compared to the original ${ }^{19}$.

Thouaty, et al. ${ }^{28}$ (1996) demonstrated that the immersion of impressions in sodium hypochlorite solution gives rise to an expansion in the elastomeric impression material. Compared to the original dimensions of the areas, in most cases such expansion allows a dimensional precision better than that observed on an impression that was not immersed. In the present study, this expansion promoted an improvement in the clinical procedures of prosthesis fitting.

Nevertheless, $35.4 \%$ of the dental professionals interviewed by Pavarina and Bussatore ${ }^{18}$ (1996) did not accomplish any type of disinfection of impressions because they thought that such procedure could cause dimensional changes in the materials.

Considering this evidence, other alternatives have been proposed for the disinfection of impressions. Studies have demonstrated the effectiveness of methods such as alginates containing antimicrobial agents in its composition ${ }^{7}$, or even the use of disinfectants as substitutes of water in the preparation of alginate ${ }^{29}$. Other studies showed the inefficacy of procedures such as ultraviolet radiation ${ }^{9}$, washing and immersion of casts in solutions, or the use of disinfectants as substitutes of water in the preparation of

TABLE 1- Means ( $\mathrm{mm}$ ) and standard deviations of the AB distances in the groups according to the time periods

\begin{tabular}{llccccc}
\hline Situation & & & & Time \\
& T0 & $s$ & T1 & $s$ & T2 & $s$ \\
\hline Control & & & & & & \\
Hypochlorite & 25.018 & 0.034713 & 25.031 & 0.024481 & 25.035 & 0.029031 \\
Glutaraldehyde & $25.018^{*}$ & $0.034713^{*}$ & 25.024 & 0.019514 & 25.029 & 0.043168 \\
\hline
\end{tabular}

* Values repeated from the control group

TABLE 2- Means ( $\mathrm{mm}$ ) and standard deviations of the BD distances in the groups according to the time periods

\begin{tabular}{|c|c|c|c|c|c|c|}
\hline \multirow[t]{2}{*}{ Situation } & \multicolumn{6}{|c|}{ Time } \\
\hline & TO & $s$ & T1 & $s$ & T2 & $s$ \\
\hline Control & 4.810 & 0.008833 & 4.806 & 0.006427 & 4.804 & 0.011225 \\
\hline Hypochlorite & $4.810^{*}$ & $0.008833^{*}$ & 4.812 & 0.005043 & 4.805 & 0.011262 \\
\hline Glutaraldehyde & $4.810^{*}$ & $0.008833^{*}$ & 4.804 & 0.011658 & 4.804 & 0.009593 \\
\hline
\end{tabular}

* Values repeated from the control group 
dental plaster, what according to Soares and Ueti ${ }^{26}$ (2001) may bring about irreversible alterations to the hardness and surface of the plaster.

The spray technique shows a similar antimicrobial activity compared to the immersion method. However, the spray does not affect the dimensional stability as the process of immersion. According to Mathyas, et al. ${ }^{12}$ (1990) and Dellinger, et al. ${ }^{5}$ (1990), this difference is not observed with a time period of 10 minutes for disinfection.

The method employed in this investigation took into account the recommendation of several authors $7,8,12,13,15$, that 10 minutes of immersion in the two solutions tested are enough to eliminate the viable bacteria from the surface of the condensation silicone. However, the need for an antispore effect highlighted the importance to verify the effects when this time period was increased up to 20 minutes.

According to Durr, et al. ${ }^{6}$ (1987), even though procedures to test the effectiveness of the disinfectant solutions against AIDS and hepatitis B virus have not been developed yet, it is apparent that immersion for 10 minutes in high-level germicide such as a sodium hypochlorite solutions or potentiated glutaraldehyde will allow the achievement of a material with a virus-free surface.

The silicone tested presented high dimensional stability during the 20-minute period on the table, confirming the study of Sawyer, et al..$^{25}$ (1974). The largest change verified on this time period was $0.14 \%$, in the $\mathrm{BD}$ distance. This alteration is not statistically or clinically significant and may also be worthless, taking into account the deficiencies of the measurement method. Due to the high precision and high sensibility of the instrument, besides other factors already described by Chong and Doking ${ }^{4}$ (1969), variations of $17 \mu \mathrm{m}$, as observed in the $\mathrm{AB}$ distance, can be included in the limits of miscalculation of the method.

This may similarly be noticed in the other dimensional alterations observed among the groups. Therefore, there was no difference between disinfection with silicon Optosil - Xantopren for 10 or 20 minutes, or absence of disinfection. There also was no significant difference between the alterations caused by the two solutions tested.

This result is also demonstrated by other authors ${ }^{3,22,27}$. The significant expansions caused by the disinfectant solutions as shown by Thouati, et al. ${ }^{28}$ (1996), which can offset the polymerization shrinkage and therefore improve the precision of the resulting cast, may require a long time of maintenance in the disinfectant.

Oda, et al. ${ }^{16}$ (1995) confirm the presence of an improvement in the precision of impressions in condensation silicone immersed in disinfectant. The alterations vary according to the disinfectant employed because the vaporization of alcohol as a by-product of polymerization is inhibited.

\section{CONCLUSIONS}

The results observed allowed the following conclusions: - The condensation silicone Optosil - Xantopren is dimensionally stable when allowed to rest on the table for 20 minutes after the impression.

- Disinfection of the impressions by immersion in $1 \%$ sodium hypochlorite solution or $2 \%$ glutaraldehyde solution for 20 minutes did not yield significant linear dimensional changes in the condensation silicone Optosil - Xantopren.

- There was no statistically significant difference between the dimensional stability of silicone impressions immersed in the $1 \%$ sodium hypochlorite solution or in $2 \%$ glutaraldehyde solution.

- The dimensional changes observed in the silicone are not different as to the time periods of 10 or 20 minutes.

- The disinfection of condensation silicone impressions can be a safe method for preservation of the dimensional stability of the material. Reduction of the risks of contamination in the clinical and laboratory environment during the dental practice is very important.

\section{REFERENCES}

1- American Dental Association,. Council of Dental Materials and Devices. Specification No. 19 for non-aqueous, elastomeric dental impression material. J Amer Dent Assoc 1977 Apr; 94(4):733-41.

2- Brasil, Ministério da Saúde. Coordenação de controle de infecção hospitalar. Processo de artigos e superfícies em estabelecimento de saúde. 2. ed. Brasília: Ministério da Saúde; 1994.

3- Bergman M, Olsson S, Bergman B. Elastomeric impression materials: dimensional stability and surface detail sharpness following treatment with disinfection solutions. Swed Dent J 1980;58:161-7.

4- Chong $M P$, Docking AR. Some setting characteristics of elastomeric impression materials : part I. Aust Dent J 1969 Oct; 14:295-301.

5- Dellinger EL, Williams KJ, Setcos JC. Influence of immersion and spray disinfectants on alginate impressions [abstract n. 2045]. J Dent Res 1990;69 (special issue): 364.

6- Durr DP, Novak EV. Dimensional stability of alginate impressions immersed in disinfecting solutions. J Dent Child 1987 Jan/Feb;54(1): 45-8.

7- Ghani F, Hobkirk JA, Wilson M. Evaluation of a new antisepticcontaining alginate impression material. Brit Dent J 1990 Aug; 169(34): 83-6.

8- Johansen RE, Stackhouse Jr. JA. Dimensional changes of elastomers during cold sterilization. J Prosthet Dent, 1987 Feb;57(2):233-6.

9- Larsen T, Fiehn NE, Peutzfeldt A, Öwall B. Disinfection of dental impressions and oclusal records by ultraviolet radiation. Eur J Prosthodont Restor Dent 2000 Jun;8(2):71-4.

10- Leung RL, Schonfeld SE, Gypsum cast as a potential source of microbial cross-contamination. J Prosthet Dent 1983 Feb;49(2):21011 .

11- Martin MV. Infection Control in dental enviroment. London: Matin Dunitz; 1991.

12- Mathyas J, Dao N, Caputo AA, Lucatorto FM. Effects of disinfectants on dimensional accuracy of impression materials. J Prosthet Dent 1990 July;64(1)25-31. 
13- Merchant VA. Infection control in the dental laboratory environment. In: Cottone AA, Terezhalmy GT, Molinari JA. Practical infection control in dentistry. Baltimor : Williams \& Willians; 1996. p. $239-54$

14- Merchant VA, Mcneight MK, Ciboro Wski CJ, Molinari JA. Preliminary investigation of a method for disinfection of dental impressions. J Prosthet Dent 1984 Dec;52(6):877-9.

15- Nascimento WF, Borges ALS, Uemura ES, Moraes JV. Desinfecção de moldes: como, quando e por quê. Rev Assoc Paul Cir Dent 1999 jan/fev;53(1):21-4.

16- Oda Y, Matsumoto T, Sumii T. Evaluation of dimensional stability of elastomeric impression materials during disinfection. Bull Tokyo Dent Coll 1995 Feb;36(1):1-7.

17- Osorio AF, Fatturi CC, Poisl MIP, Samuel SMW. Avaliação da eficácia de agentes químicos na desinfecção de moldes de alginatos. Rev Fac Odontol Porto Alegre 1997 jul;39(1):17-9.

18- Pavarina AC, Bussadore CMC. Desinfecção de moldes e modelos: avaliação dos procedimentos entre profissionais. Odontol Clínica 1996 jan/jun;6:45-50

19- Phillips R W. Skinner materiais dentários. 9. ed. Rio de Janeiro: Guanabara Koogan; 1993.

20- Poulos JG, Antonoff LR. Disinfection of impressions: methods and effects on accuracy. N Y Dent J 1997 Jun/Jul;63(6):34-6.

21- Rios MP, Morgano SM, Stein RS, Rose L. Effects of chemical disinfectant solutions on the stability and accuracy of the dental impression complex. J Prosthet Dent 1996 Oct;76(4):356-62.
22- RHODES, C. J.; et al. Effect of commercial glutaraldehyde solution on elastomeric impression materials [abstract n. 619]. J Dent Res 1985;64(special issue):243.

23- Runnells RR. An overview of infection control in dental practice. J Prosthet Dent 1992 May;67(5):628-31.

24- Samaranayake LP, Scheutz F, Cottone JA. Controle da Infecção para a equipe odontológica. São Paulo: Santos; 1995.

25- Sawyer HF, Dilts WE, Aubrey ME, Neiman R. Accuracy of casts produced from the three classes of elastomer impression materials. J Amer Dent Assoc 1974 Sep;89(9):644-8.

26- Soares CR, Ueti M. Influência de diferentes métodos de desinfecção química nas propriedades físicas de troquéis de gesso tipo IV e V. Pesqui Odontol Bras 2001 out/dez;15(4):334-40.

27- Storer R, Mccabe JF. An investigation of methods available for sterilizing impressions. Brit Dent J 1981 Oct;151(217):217-9.

28- Thouaty A, Deveaux E, Iost A, Behin P. Dimensional stability of seven estomeric impression materials immersed in disinfectants. J Prosthet Dent 1996 July;76(1):8-14.

29- Touyz LZ, Rosen M. Disinfection of alginate impression materials using disinfectants as mixing and soak solution. J. Dent 1991;19(4): 255-7.

30- Trevelyan MR. The prosthetic treatment of hepatitis B antigen positive patients. Brit Dent J 1974 July;137(2):63-4. 